Marquette University

e-Publications@Marquette

Spanish Languages and Literatures Research and

Languages, Literatures and Culture Faculty

Publications

Research and Publications

$1-1-2017$

\title{
Places/Non-Places: Galicia on the Road of St. James
}

Eugenia Afinoguénova

Marquette University, eugenia.afinoguenova@marquette.edu

Published version. "Places/Non-places: Galicia on the Road of St. James," in Rerouting Galician Studies: Multidisciplinary Interventions, edited by Benita Sampedro Vizcaya, Jose A. Losada Montero. Cham, Switzerland: Palgrave Macmillan, \{2017\}: 139-150. DOI. (c) 2017 The Author(s). Used with permission. 


\section{Places/Non-places: Galicia on the Road of St. James}

\section{Eugenia Afinoguénova}

Turgalicia, the public agency reporting to the Culture, Education, and Tourism department of the autonomous government of Galicia, greets its English-speaking virtual visitors with a pun: "Galicia, the best way." Galician and Castilian versions advertise the region as "o bo camiño" and "el buen camino" ["the good way"], revealing the slogan's links to the tradition of walking the medieval paths, known as the Road of St. James, leading from different parts of Europe to the crypt in the Cathedral of Santiago de Compostela where St. James is said to be buried. Playing on the pilgrims' customary salutation, Buen camino [Enjoy the road/ May your road be good], the motto suggests a continuity between the region's touristic appeal (for which Turgalicia, established in 1992, is responsible) and the promotion of the Road of St. James carried out by the Consello Xacobeo [The Road of St. James Council]. This institution in charge of branding, maintaining, and popularizing the roads leading to Santiago came to life in conjunction with the Presidency-at the head of the Galician government - of Manuel Fraga Iribarne, who in the 1960 s had been the designer of a tourism-driven identity for Spain. ${ }^{2}$

\section{E. Afinoguénova (ब)}

Professor of Spanish, Marquette University, Milwaukee, WI, USA

C The Author(s) 2017

B. Sampedro Vizcaya and J.A. Losada Montero (eds.),

Rerouting Galician Studies, DOI 10.1007/978-3-319-65729-5_9 
Although now the Xacobeo operates within the Ministry of Education, Culture, and Sports of Spain's central government, it owes its origins to Galicia and, specifically, to Víctor Manuel Vázquez Portomeñe, the public official responsible for Institutional Relations and the Speaker of the regional government during Fraga's presidency. ${ }^{3}$ In 1992, anticipating a rapid succession of Holy years $(1993,1999$, and 2004), the Xunta [the government of Galicia] mediated between the regions represented on the French and Northern Spanish Routes to create the Consello Xacobeo. Within this framework, Xacobeo Galicia, a regional branch, took on the task of spearheading the revalorization, diversification, and international projection of these routes in the Galician territory.

Why do the Galician tourism authorities continue to rely so closely on the Road of St. James at the time when diversification of tourism is in fashion? Given the weight of tourism branding in regional policymaking, this is a significant question for Galician Studies. Until recently, however, research on Galicia has remained relatively disconnected from the Road of St. James phenomenon, which has been a less popular topic of inquiry in Galicia or Spain than in Britain and the USA. This began to change with the foundation, in 2011, of the Institute for Pilgrimage Studies at the College of William and Mary, whose yearly symposia became an interdisciplinary venue where medievalists, theologians, and sociologists could meet experts on Galicia and Spain. It became clear that the history of the Road makes Galicia, especially well positioned to generate a new type of debate, decentralized and transnational in nature. ${ }^{4}$ Still, at first glance, the Road of St. James might seem a strange place for regional identity-making. To begin with, it is not a place at all, but rather an itinerary: A sequence of places to go through, which, albeit constructed as historical, also overlap in an intriguing way with Marc Augé's concept of "non-places." Indeed, as this chapter will demonstrate, the cultural encoding of the Road offers a surprising balance of history, identity, and what Augé terms "supermodernity," which requires a careful reconsideration of the type of branding that emerges when regional self-identification meets tourism and pilgrimage:

If a place can be defined as relational, historical and concerned with identity, then a space which cannot be defined as relational, or historical, or concerned with identity will be a non-place. The hypothesis advanced here is that supermodernity produces non-places, meaning spaces which are not themselves anthropological places and which, unlike Baudelairean 
modernity, do not integrate the earlier places: instead these are listed, classified, promoted to the status of 'places of memory,' and assigned to a circumscribed and specific position. ${ }^{5}$

As scenarios of an ongoing rite of passage, the towns and cities along the Road occupy the liminal space of the ritual. ${ }^{6}$ Yet thinking of a place as liminal, as a spot that is "neither here, nor there," is hardly conducive to competitive place-identities. ${ }^{7}$ Besides, how can one configure a regional image based on a larger itinerary without triggering undesirable consequences, such as regional competition? Add to this that the rise of the pilgrimage route between the twelfth and fifteenth centuries, responding to the European consolidation of "Christendom," as well as its revival from the late twentieth century onwards, are events of a transnational scale, and the complexity of grounding an identity project for Galicia on the success of the Camiño - the term by which I will refer here to those sections of the pilgrimage path that crosses through Galician territorywill become clear.

These apparent difficulties, however, have not stopped the autonomous government of Galicia from developing a program of regional revival around the Camiño phenomenon. Far beyond economic planning, the comeback of the Camiño since the 1980s came across as an opportunity to produce a modern ethnic identity. During the years of the presidency of the Partido Popular in Galicia, the Ethnography Section of the regional Department of Culture undertook an ambitious program of creating a special ethnographic inventory with the aim of binding the Camiño to the renewed notions of Galician ethnicity. Between 1993 and 1995, ethnographers, local historians, tourism promoters, and infrastructure engineers, among others, were hired or received grants and fellowships to contribute lists of all monuments and cultural practices that could set the foundation for the region's ethnic archive that the Camiño would reinforce, multiply, and carry abroad. ${ }^{8}$ Such a renovation of ethnic identity with an eye on the twenty-first century was not unique to Galicia: In the 1990s, other autonomous governments within Spain also drafted similar programs for recasting their territories in ethnic terms, using notions such as "cultural landscapes" and "ethnographic parks." The volume Aproximación a un inventario del patrimonio etnográfico vasco, ${ }^{9}$ produced by the Basque Cultural Observatory, contains a useful overview of the notions of ethnically relevant heritage that different regional administrations were using. ${ }^{10}$ The regionalization 
of a revived transnational route was not unprecedented either, since similar inventories have been drafted in other parts of Spain, including Asturias, La Rioja, and-most radically-Cataluña, which, following the Strategic Tourism Development Plan for 2004-2010, is now promoting the "Camí de Sant Jaume en Catalunya," with its own layered road signs and emblems. ${ }^{11}$

The Associations of Friends of the Road of St. James and a wide range of other supranational, national, regional, and local institutions and civic groups - from the American Pilgrims on the Camino and the Londonbased Confraternity of Saint James to municipalities and pilgrim hostels associations-are working together on producing and maintaining the Road in terms that are both practical and symbolic. These diverse entities have a common tendency to treat the route as a place-a destination rather than an itinerary-and are driven by a shared desire to harness it as heritage. Their attempts at ethnic branding of Galicia within the framework of the Camiño reflect the not-always-holy foundations of Europe, and the roles reserved for Galicia in European geopolitics. ${ }^{12}$ As Eva Mouriño López and Sasha Pack have argued, the high profile of the Road of St. James - which, after the visit of Pope John Paul II in 1982 was recast as a spiritual and cultural prototype for the present-day Europeanism-derives from a strong, yet unsatisfied, need for a version of common past that could consolidate Europe. The exaltation of a route that had been established in the Middle Ages partially in order to connect the reconquered areas of the Iberian Peninsula to Christendom and to assist in its repopulation by the Pope's subjects, made this so-called cultural itinerary vulnerable to a series of unsettling questions about the role of Islam, xenophobia, and territorial policy.

The array of questions expanded as the Road gained increasing recognition in the international arena. It was recognized as a UNESCO World Heritage Site (in 1985); Santiago de Compostela was named European Cultural Capital in 2000; the Road was designated as the First European Cultural Route in 1987; and the Spanish and French monuments along the road were added to UNESCO's World Heritage List in 1993 and 1998 respectively. More recently, the Road was declared Intangible Cultural Heritage of the World (for northern Spain, excluding Cataluña) by the International Bureau of Cultural Capitals, in 2009. Official addresses and speeches accompanying this process featured abundant metaphors of encounter and cross-cultural communication. At the 1985 ceremony inscribing Santiago de Compostela into UNESCO's 
list of World Heritage Sites, Louis Jung, President of the Parliamentary Assembly of the European Council, described the pilgrims as follows:

They were guided by their common faith but also by their will to meet their neighbors, communicate with them, exchange goods and culture ... This leads to developing friendships among people, and a sense of belonging to the same community that I dare to call European. ${ }^{13}$

Yet, anyone familiar with Book $\mathrm{V}$ of the twelfth-century compilation of liturgical texts and legends related to St. James and the pilgrimage known as the Codex Calixtinus or Liber Sancti Jacobi - which offers practical guidance to pilgrims en route to Santiago-has seen the limitations of these friendships and this sense of community, in the medieval context. For instance, the anonymous French author of Book V informs us:

The Navarrese ... dress most poorly and eat and drink disgustingly. The whole household of a Navarrese, to be sure, the servant no less than the master, the maid no less than the mistress, eat from a single dish all the food mixed together; and they eat not with spoons but with their own hands and furthermore drink from a single cup. If you saw them eating, you would take them for dogs or pigs in the very act of devouring; if you heard them speaking, you would be reminded of the barking of dogs.

This is a barbarous nation, distinct from all other nations in habits and ways of being, full of all kind of malice, and of black color. Their face is ugly, and they are debauched, perverse, perfidious, disloyal and corrupt, libidinous, drunkard, given to all kinds of violence, ferocious and savage, impudent and false, impious and uncouth, cruel and quarrelsome, incapable of anything virtuous, well-informed of all vices and iniquities. ${ }^{14}$

Galicians fare a bit better: "[They] are more like us French people than other Spanish savages, but nevertheless they can be hot-tempered and litigious." 15 Still, a strict demarcation between "us French people" and the rest of the people, to whom similarities to "Saracens" are attributed, is maintained throughout the medieval text. There is little echo of these ethnic and religious conflicts in recent cultural campaigns aimed at tracing European identity back to the pilgrimage. None of these conflicts have mattered in the pro-European context of the period since the 1980s when, in Sasha Pack's reading, Christian ecumenism took the Road to return into European politics under the guise of shared cultural values. 
Pack suggests that we take a close look at the "conch shell emblem that the Franco government had placed on road signs [in the 1960s]; the new markers would mimic the nascent European flag, bearing a stylized yellow abstraction of a conch shell against a solid blue background." 16

It was not, however, until the regulations of the European Union's Common Agrarian Policy took force, and the conservative government of Manuel Fraga came to power in 1990, that a dialogue on the Camiño fully emerged. This debate was catalyzed by the EU restrictions on agricultural and milk production, which assured an end to the "esquemas de autoconsumo" [self-consumption schemes], which had constituted the foundation of the Galician economy. In a region with low levels of urbanization and population growth, the task was "un enfoque ruralista más que un enfoque estrictamente agrarista" [a ruralist, rather than a strictly agrarianist, approach]. ${ }^{17}$ Galicia's mission within the European Union became to reinvent the rural sphere, transforming it in a way that diminished its dependence on the agricultural sector. ${ }^{18}$ Culture, rather than agriculture, has therefore become one of the driving forces behind the high profile of the Camiño in this process of reinvention, and in the rebranding of Galicia. Still, evidence suggests that the recasting of pilgrimage as a route of cultural tourism has proven most beneficial for the city of Santiago itself and, to a lesser degree, for other medium and large size towns, while failing to reverse the depopulation of small towns and villages. ${ }^{19}$

Modern processes of standardization, infrastructure management, and movement control are partially responsible for these imbalances. During the 1990s, in preparation for the sequence of successive Xacobeo holy years, the Xunta invited a number of experts to contribute their insights concerning local ethnic heritage. Yet the strategies for transforming stretches of old highways and mud roads into freshly marked itineraries followed a desarrollista mindset of clear-cut routes connecting tourism centers. The anthropologists Xosé Antón Fidalgo Santamariña and Yolanda Barriocanal López leave us with compelling stories that document the pains triggered by this standardization. ${ }^{20}$ Earlier generations of pilgrims - these scholars remind us-had never followed a single route that could be simply recognized, typified, and marked with the blue and yellow conch signs. Major Roman roads in the region, while eventually integrated into medieval pilgrimage routes, had led towards Braga, rather than to Santiago de Compostela, and proved difficult to revalorize in the framework of the Camiño promotion by the Xunta de Galicia. ${ }^{21}$ 
One fundamental problem is the dominance of the Spanish central state in controlling the tourism blueprints of autonomous regions within the country. Since 1988, the central government in Madrid, acting through the public agency Turespaña, has regulated Spain's national brand-the Marca España-and its international distribution. Autonomous regions including Galicia need to operate within this framework. Rooted in the early twentieth-century idea of diversity within unity, this centralist framework creates competition between regions for recruiting visitors, and especially for having the chance to branch out to the international arena. ${ }^{22}$ Just as all other promoters working for the Autonomous Communities, Galician tourism authorities use every Xacobeo year as a precious outlet to relaunch the regional image on the world markets. Furthermore, since the Road of St. James has the potential of remaining the sole image that the Xunta can transmit abroad, the high weight of the Camiño in Galicia's tourism should come as no surprise.

More surprising is the diversity of meanings attached to the Road. The recent revival of the Camiño has produced a shift in the interpretations ascribed to the places that it traverses, now imbued with layers of historical, cultural, and anthropological auras that turn them into highly variegated "places of memory." 23 When the European community first expressed an interest in the route, the Spanish Pilgrims' Association perceived it as a danger: The fashion for pilgrimage tourism would put an end to the Road's real, religious, purposes. ${ }^{24} \mathrm{~A}$ decade later, however, from inside Galicia, there emerged a different impulse: that of adding to the Christian road to Santiago a pagan section. In 1997, the route from Santiago to coastal towns of Muxía and Fisterra was not even marked. ${ }^{25}$ Now, however, two decades later, it has emerged as the road's most "authentic" stretch and as one whose mystical and pagan connotations are perceived as conducing to a sense of place that is more deeply rooted in the Galician spirit. ${ }^{26}$ The mystical nature of Galicia is, of course, a commonplace originating in the work of late nineteenth- and early twentieth-century Galician nationalists. Pagan mysticism has now been fused to the secularized route, making this dimension of pilgrimage an effective tool for Galician image-making, and a crucial component in the "shifting relations between cultural identity, cultural history, cartography and aesthetics" in present-day Galicia. ${ }^{27}$

What remains unresolved is the place of Galicians themselves in this revivified Road. Are they to find their image as the Road's participants, or simply as perennial hosts, exploiting touristic interest in "monumental 
time" and producing convenient narratives about their communities as ancient builders of these monuments? ${ }^{28}$ Arturo Soria y Puig, an engineer and prolific promoter of the Road, suggested a wide range of potential participants: "With a little imagination and a gentle push, the Road of St. James could be transformed into the first linear sacred, historical, and artistic park serving both the inhabitants of the towns that it crossesfor short outings and walks - and outsiders wishing to undertake a pilgrimage for religious reasons, or to have a new pleasant experience of spending a month or a week walking or riding a horse through the country, along a historical route full of possibilities that people from Central Europe find more or less exotic." 29 The inhabitants of the towns and the villages on the Camiño are invited to join in: but the nature and meaning of their itinerary, beyond short outings and walks in a park, remain open.

\section{Notes}

1. Accessed July 2016. http://www.turismo.gal/portada?langId=en_US.

2. For tourism-induced imaginaries of desarrollismo and its intellectual foundations, see Pack Tourism and dictatorship; Crumbaugh, Destination dictatorship; Afinoguénova, "Unity, stability, continuity" and "La España negra en color."

3. Novello et al., Xacobeo, 60-63.

4. Sánchez y Sánchez and Hesp, "Introduction." See also Goodman and Greenia, "Santiago: Patrón de una nación."

5. Augé, Non-places, 77-78.

6. The classic description of pilgrimage as a practice of liminality is contained in Turner and Turner's Image and pilgrimage. Earlier, in "Liminality and communitas," Victor Turner developed a popular model of liminality and the transient forms of communities (communitas) that it engendered. The model has since received numerous criticisms, yet the idea of pilgrimage as a liminal practice has persisted. See Morinis, Sacred journeys, and Badone and Roseman, Intersecting journeys, among others.

7. Turner, "Liminality and communitas," 95.

8. Braña Rey, "Accións patrimoniais," 54.

9. Observatorio Cultural Vasco, Aproximación, 9-20.

10. For an in-depth overview of the theoretical issues behind the recent mobilization of ethnography for renovating place-identities in rural Spain, see Narotzky and Smith, Immediate struggles, 203-220.

11. See also Álvarez Sousa et al., "Estructura organizativa," 11.

12. See Méndez, "Galicia, región de Europa," and Galicia en Europa. 
13. "Una fe común les guiaba pero también una voluntad de conocer a sus vecinos, de comunicarse con ellos, de intercambiar bienes y cultura ... Ello da lugar a un desarrollo de la amistad entre los pueblos y al sentimiento de pertenecer a una misma comunidad que me atrevo a calificar de europea. Quoted in Mouriño, "Un camiño recuperado."

14. Pilgrim's Guide to Santiago de Compostela, 94.

15. Codex Calixtinus, Book V.

16. Pack, "Revival," 366.

17. Anonymous, Manual, 117-118.

18. Although-it may be noted-the funding for rural development that Galicia received from the European Union's Common Agrarian Program doubled the European average (44\% vs. $20 \%)$ : Anonymous, Manual, 117-118.

19. See Precedo Ledo et al., "Turismo cultural," 216-217.

20. See Barriocanal López, "Delimitación," 91-100, and Fidalgo Santamariña, "Camiños parroquiais," 67-80.

21. Barriocanal López, "Delimitación," 91.

22. Garrido Lora, "Publicidad turística," 78.

23. Nora, "Entre mémoire."

24. See "Nuevos caminos; nueva luz," in Revista Peregrino (1987).

25. Vilar Álvarez, "Antropoloxía no Camiño," 42-43.

26. Herrero, "Atracción turística."

27. Hooper, Writing Galicia, 171.

28. Herzfeld, "Rhythm," 110.

29. "Con un poco de imaginación y empuje, el Camino de Santiago podría convertirse en el primer parque lineal de carácter sacro-histórico-artístico, al servicio tanto de los habitantes de las ciudades que atraviesa-para cortos paseos o excursiones-, como los foráneos deseosos de peregrinar por motivos religiosos o de tener una experiencia nueva y gratificante, cual es la de pasarse un mes o una semana andando o cabalgando por medio del campo y siguiendo una ruta llena de historia y de sugerencias más o menos exóticas para un centroeuropeo," Arturo Soria y Puig, quoted in Mouriño, "Un camiño recuperado," 57.

\section{BIBLIOGRAPHY}

Afinoguénova, Eugenia. “'Unity, stability, continuity': heritage and the renovation of Franco's dictatorship in Spain, 1957-1969." International Journal of Heritage Studies 16.6 (2010): 371-387.

. "La España negra en color: El desarrollismo turístico, la auto-etnografia y España insólita (Javier Aguirre, 1965)." Archivos de la filmoteca: Revista de estudios históricos sobre la imagen 69 (April 2012): 39-57. 
Álvarez Sousa, Antón, Alfonso Gomis Rodríguez, and Miguel Ángel Gallego Valiña. "Estructura organizativa e imagen promocional del Camino de Santiago." ROTUR/Revista de Ocio y turismo 3 (2010): 11-38.

Anonymous. The Pilgrim's Guide to Santiago de Compostela [Book V of Codex Calixtinus]. Transl. by William Melczer. New York: Italica Press, 1993.

Anonymous. "Nuevos caminos; nueva luz." Revista Peregrino 0 (1987): 3.

Anonymous. Manual: Pasado, presente y futuro de la PAC, s/a. <http://www. unionsagrarias.org/futurodelaPAC/docs/manualPAC.pdf\$.

Augé, Marc. Non-places. Introduction to an Antbropology of supermodernity. Trans. John Howe. London and New York: Verso, 1995.

Badone, Ellen E., and Sharon R. Roseman, eds. Intersecting journeys: The Anthropology of pilgrimage and tourism. Chicago: University of Illinois Press, 2004.

Barriocanal López, Yolanda. "Delimitación e protección do Camiño de Santiago, Vía da Prata. Estado da cuestión." IV Congreso de patrimonio etnográfico galego. Os camiños de Santiago: miradas e experiencias, eds. Xosé Manuel Cid Fernández, Fátima Braña Rey, Xulio Fernández Senra, Mariló Fernández Senra, 91-100. Ourense: Deputación de Ourense, 2012.

Braña Rey, Fátima. "As accións patrimoniais no Camiño de Santiago a través da análise das fontes como lugares antropolóxicos." IV Congreso de patrimonio etnográfico galego. Os camiños de Santiago: miradas e experiencias, eds. Xosé Manuel Cid Fernández, Fátima Braña Rey, Xulio Fernández Senra, Mariló Fernández Senra, 54-60. Ourense: Deputación de Ourense, 2012.

Crumbaugh, Justin. Destination dictatorship. The spectacle of Spain's tourist boom and the reinvention of difference. Albany: SUNY Press, 2009.

Fidalgo Santamariña, José Antonio. "Dos camiños parroquiais aos camiños especiais: as rutas de peregrinación ao seu paso por San Xulián de Grixalba (Sobrado dos Monxes)." IV Congreso de patrimonio etnográfico galego. Os camiños de Santiago: miradas e experiencias, eds. Xosé Manuel Cid Fernández, Fátima Braña Rey, Xulio Fernández Senra, Mariló Fernández Senra, 67-80. Ourense: Deputación de Ourense, 2012.

Garrido Lora, Manuel. "La publicidad turística en Andalucía (2002-2005): Andalucía sólo hay una. La tuya y Andalucía te quiere." Questiones publicitarias 1.10 (2005): $77-97$.

Gennep, Arnold van. The rites of passage. Trans. Monika B. Vizedom and Gabrielle L. Caffe. London: Routledge, 1960 [1909].

Goodman, Ryan T. and George D. Greenia. "Santiago: Patrón de una nación y protector de su monarquía y un ideal posnacionalista." Hispania. The Journal of the American Association of Teachers of Spanish \& Portuguese. Forthcoming.

Herrero, Nieves. "La atracción turística de un espacio mítico: peregrinación al cabo de Finisterre." Pasos: Revista de Turismo y Patrimonio Cultural 7.2 (2009): 163-178. 
Herzfeld, Michael. "Rhythm, tempo, and historical time: Experiencing temporality in the neoliberal age." Public Archaeology: Archaeological ethnographies 8.2-3 (2009): 108-123.

Hooper, Kirsty. Writing Galicia into the world: New cartographies, new poetics. Liverpool: Liverpool University Press, 2011.

Méndez, Lourdes. "Galicia, región de Europa: dimensiones europeístas del imaginario culturalista de la Xunta." Revista de Antropología Social 80.12 (2003): 79-97.

Galicia en Europa. El lugar de las artes plásticas en la política cultural de la Xunta. Sada: Edicións do Castro, 2004.

Morinis, Alan, ed. Sacred journeys: the Anthropology of pilgrimage. Westport and London: Greenwood Press, 1992.

Mouriño López, Eva. Activación patrimonial e ritualización no proceso de revitalización do Camiño de Santiago. Ph.D. Diss., unpublished. Universidade de Santiago de Compostela, 2002.

. "Un Camiño recuperado. Políticas da memoria." IV Congreso de patrimonio etnográfico galego. Os camiños de Santiago: miradas e experiencias, eds. Xosé Manuel Cid Fernández, Fátima Braña Rey, Xulio Fernández Senra, Mariló Fernández Senra, 61-68. Ourense: Deputación de Ourense, 2012.

"Un camiño recuperado," La Voz de Galicia, 13 July 1985: 65.

Narotzky, Susana, and Gavin Smith. Immediate struggles. People, power, and place in rural Spain. Berkeley: Berkeley University Press, 2006.

Nora, Pierre, "Entre mémoire et histoire." In Les Lieux de mémoire, ed. Pierre Nora, vol. I Paris: Gallimard, 1984: xviii-xli.

Novello, Simone, Fidel Martínez Roget, Pilar Murias Fernández, et al., eds. Xacobeo: De un recurso a un evento turístico global. Santiago de Compostela: Andavira Editora, 2013.

Observatorio Cultural Vasco. Aproximación a un inventario del patrimonio etnográfico vasco. 2005. Web accessed November 2016. <http://www. kultura.ejgv.euskadi.net/r46-19803/es/contenidos/informacion/keb_publicaciones/es_publicac/adjuntos/Resumen_patrimonio.pdf $>$.

Pack, Sasha D. Tourism and dictatorship. Europe's peaceful invasion of Franco's Spain. New York: Palgrave Macmillan, 2006.

"Revival of the pilgrimage to Santiago de Compostela: The politics of religious, national, and European patrimony, 1879-1988." The Journal of Modern History 82.2 (June 2010): 335-367.

Precedo Ledo, Andrés, Arturo Revilla Bonín, Alberto Míguez Iglesias. "El turismo cultural como factor estratégico de desarrollo: el camino de Santiago." Estudios geográficos LXVIII.262 (January-June 2007): 205-234.

Reigosa, Carlos G. "El Camino de Santiago: ¿Hacia una nueva identidad?” In El Camino de Santiago (cursos de verano de El Escorial, 1993-94), ed, Luis Blanco Vila, 37-48. Madrid, 1995. 
Sánchez y Sánchez, Samuel, and Annie Hesp, eds. The Camino de Santiago in the 21 st Century. Interdisciplinary Perspectives and Global Views. London and New York: Routledge, 2015.

Turner, Victor, "Liminality and communitas." The ritual process. Structure and anti-structure. Chicago: Aldine Publishing, 1969: 94-130.

Turner, Victor and Edith Turner. Image and pilgrimage in Christian culture. New York: Columbia University Press, 1978.

Vilar Álvarez, Manuel. "Por que a antropoloxía no Camiño?” IV Congreso de patrimonio etnográfico galego. Os camiños de Santiago: miradas e experiencias, eds. Xosé Manuel Cid Fernández, Fátima Braña Rey, Xulio Fernández Senra, Mariló Fernández Senra, 39-47. Ourense: Deputación de Ourense, 2012. 